\title{
THE PATHOS OF THE LIFE AND MINISTRY OF JEREMTAH.
}

\author{
By Professor B. R. Downer, Kansas City Baptist \\ Theological Seminary.
}

The personal life of Jeremiah is better known to us than that of any other prophet. From his own writings we become acquainted not only with the principal events of the history with which he had so much to do, but with his mental conflicts and emotions. In Isaiah's book we have few references to his personal affairs. But we are carried with Jeremiah through his various experiences, we feel his passionate earnestness and are touched with the sadness of his lamentations over the sins of his people, as though the weight of them were crushing his own heart.

Before coming to the consideration of the subject of this paper it may be helpful to recall some of the main facts of the prophet's life. A native of Anathoth, a small place three miles northeast of Jerusalem, and of priestly descent, the most of his life was spent at the capital during a very stormy era preceding its downfall. His ministry, which extended over a period of forty years, exclusive of a number spent with the remnant of his countrymen in Egypt, is inseparably linked with the closing years of the kingdom of Judah preceding the Babylonian exile. His activity as prophet to Judah fell during the reigns of the last five kings, from the thirteenth year of Josiah to the close of Zedekiah's reign. After a period of comparative freedom from outside interference when Assyria was nearing its end, Palestine with all Syria was now threatened on both sides by the two great world powers, Egypt and the new Babylonian empire. Jeremiah lamented the untimely death of the good king Josiah, who met his end through interfering with the ambitious scheme of Pharaoh-necoh to extend his dominions in the north at the 
Euphrates river. This brought Jerusalem and its rulers under the sway of Egypt, but only for a brief time. In the fourth year of Jehoiakim, immediately after the fall of Nineveh, a very battle of Waterloo was fought at Carchemish, in which Necoh was defeated and driven back into his own land by Nebuchadnezzar. Jehoiakim became a subject of Babylon, but from this time to the end Egyptian diplomacy and intrigues with Egypt became a disturbing element and finally resulted in the downfall of Jerusalem. Jeremiah lived and prophesied during this turbulent period and his every endeavor was given to save if possible his people from the threatened destruction. At his call he became assured of at least two things. One was that he had been foreordained of God to this ministry, and to become a prophet to the nations. Another was that this mission would be attended with difficulties that would test to the last degree his courage and his powers of endurance.

The life of Jeremiah is one of fascinating interest, yet it is a pathetic one. It is my purpose to point out some things in which the pathos of his life and ministry is particularly revealed.

We see this first of all in the conflicts endured by one of so gentle and shrinking a nature. This disposition showed itself when he became conscious of his call to be a prophet to the nations: "Ah Lord Jehovah!" he answered, "behold, I know not how to speak; for I am a child" (1:6). Not literally a child, but feeling keenly his youth and inexperience in the face of so difficult and perilous an undertaking. God had to allay his fears: "Be not afraid because of them; for I am with thee to deliver thee" $(1: 8)$. "Be not dismayed at them, lest I dismay thee before them" (1:17). His naturally shrinking disposition is reflected in God's reassuring words: "Behold, I have made thee this day a fortified city, and an iron pillar, and brazen walls against the whole land" (1:18). The gentleness of his really poetic nature appeals strongly to us. 
Speaking of a plot against his life by his fellow townsmen, he says: "I was like a gentle lamb that is led to the slaughter; and I knew not that they had devised devices against me" (11:19).

It was a man of this nature who by his mission as prophet to a degenerate people was hurried into all kinds of conflicts. He was denounced by those who had been numbered among his friends: "I have heard the defaming of many, terror on every side. Denounce, and we will denounce him, say all my familiar friends, they that watch for my fall; peradventure he will be persuaded, and we shall prevail against him, and we shall take our revenge on him" (20:10). Many of those who laid snares for him had been the objects of his intercession. "Remember", he pleads with God, "how I stood before thee to speak good for them, to turn away thy wrath from them" (18: 20). But they brutally accused and slandered him: "Come", said they, "and let us smite him with the tongue" (18:18). That this was something more than harsh criticism we see from other references to their villainous attacks : "They bend their tongue, as it were their bow, for falsehood" $(9: 3)$; "Their tongue is a deadly arrow; it speaketh deceit: one speaketh peaceably to his neighbor with his mouth, but in his heart he layeth wait for him" (9:8). "What shall be given unto thee, and what shall be done more unto thee, thou deceitful tongue?" says the psalmist. "Sharp arrows of the mighty, with coals of juniper." In addition to denunciation and slander, he was once subjected to great indignity after a sermon in the court of the temple by Pashhur, a priest and chief officer of the temple, and also a prophet of the time-serving kind, who had him beaten and put in the stocks over night.

These brutal calumies and indignities might not have been so hard to bear by a man of a different disposition, a pugnacious character and one who rather gloried in opposition. But what must they have meant to one who 
hated strife? Who said: "Woe is me, my mother, that thou hast borne me a man of strife and a man of contention to the whole earth?"' $(15: 10)$. To a man who for sheer bitterness of spirit cursed the day of his birth (20: 14-18), and cried out in his anguish, "Why is my pain perpetual, and my wound incurable, which refuseth to be healed?"' (15:18). Unmerited opposition and abuse by one who seeks the good of his fellow men is always a sad thing, but infinitely more so when it falls to the lot of one of gentle spirit, whose whole nature is alien to the turbulent life he daily endures.

Another element in the pathos of the life and ministry of Jeremiah is the loneliness of the prophet and his lack of sympathy. He stood almost alone in denouncing the sins of his people and foretelling judgment. Some others of the prophets, it is true, belong to this period. Besides Ezekiel at the Chebar and Daniel in Babylon, Zephaniah, Nahum and Habakkuk were his contemporaries in Judah. But Nahum was concerned chiefly with the fall of the mighty city of Nineveh, the ancient enemy of his people. Habakkuk beholds the oncoming Chaldeans in their world conquests, but his attitude is that of one perplexed over the mysteries of divine providence as seen in their ruthless campaigns, rather than that of a prophet of judgment upon the sins of Judah. Zephaniah probably began his ministry in the early days of Josiah, before the reformation, and at about the same time as Jeremiah. He announces in true prophetic style the "day of wrath, that dreadful day", which is soon to overwhelm Jerusalem, and warns his countrymen to seek Jehovah. But his ministry so far as we can judge from his book appears to have been brief. Other prophets, unknown to us, may have proved themselves true men of God in these trying days. But Jeremiah stood almost single-handed against the great mass of so-called prophets. They were men with no vision from God, but with a message vastly more acceptable to the multitude than the stern one of Jeremiah. They 
were optimistic as to the outcome, even predicting no more than a decade before the fall of the city, that the vessels of the temple already carried away by Nebuchadnezzar would soon be returned $(27: 16)$. One of their number, Hananiah, in order to discredit Jeremiah, took hold of the wooden yoke which the prophet was wearing as a sign and broke it from his neck, saying, "Thus saith Jehovah: Even so will I break the yoke of Nebuchadnezzar king of Babylon within two full years from off the neck of all the nations' (28:11). So hostile were these prophets that they, with the priests, had sought to have him condemned to death after his great sermon against trust in the temple, in which he had said that, so far from saving them, this house should become like Shiloh.

Harder still to bear than this opposition was the indifference of the people. High and low alike they turned a deaf ear to his appeals. He had met with no response from the rabble, but turned hopefully to the more cultured: "Then I said, Surely these are poor; they are foolish; for they know not the way of Jehovah, nor the law of their God: I will get me unto the great men, and will speak unto them; for they know the way of Jehovah, and the law of their God. But these with one accord have broken the yoke, and burst the bonds"' $(5: 4,5)$. The weapons of ridicule were launched at him: "I am become", he says, "a laughing-stock all the day, every one mocketh me. For as often as I speak, I cry out; I cry, Violence and destruction: because the word of Jehovah is made a reproach unto me, and a derision all the day" $(20: 7,8)$.

In view of this lack of sympathy from the people it strikes us as sad that the prophet had no home life. Like Paul, he had felt the present distress an argument for celibacy, and had accepted as God's will for him a life without family ties. Isaiah's home life seems to have been a solace to him amid the cares of his ministry. His wife is called "the prophetess". Two of their children were given symbolical names that bore testimony to their com- 
mon faith in the truth of his messages. He could say, "Behold, I and the children whom Jehovah hath given me are for signs and for wonders in Israel from Jehovah of hosts, who dwelleth in Mount Zion" (Isa. 8:18). Ezekiel had a wife, who is characterized in God's announcement to him of his coming bereavement, as "the desire of his eyes" (Ezek. 24:16). But Jeremiah, who of all the prophets stood in greatest need of some sustaining sympathy, was, so far as earth-ties were concerned, a lonely man. He had some disciples, like Baruch, though even he seems to have regarded it something of a cross to give up earthly ambitions, and had to be counseled, "Seekest thou great things for thyself " seek them not" (45:5). It speaks volumes for the isolated position among his countrymen which Jeremiah occupied that, when he was let down into the mire of the dungeon, it was none of his own race, but an alien from Ethiopia, Ebed-melech, who had the courage to intercede with the king and rescue him (38:7ff.).

The pathos of the life and ministry of Jeremiah is again revealed in the hopelessness of the cause to which he gave his life. It is true that no cause to which a man gives his life ever is absolutely hopeless in his own thought; otherwise his action would be irrational. While our prophet yielded to the divine call under no delusion as to the nature of the task before him, yet he was not without hope of making some impression on the nation. He seems not to have expected great things from the reformation of Josiah, though he was no doubt in sympathy with it. Some have understood what he says of proclaiming the words of the covenant in the cities of Judah and the streets of Jerusalem $(11: 6)$ as referring to his part in this reformation, but there is no certain allusion to it anywhere in his book; and the dark picture he paints of the moral and spiritual condition of the people shows that he was not deceived as to the superficial character of the movement. In one place he refers to the fact that 
Judah had not returned to Jehovah with her whole heart, but feigmedly $(3: 10)$. Yet in spite of the gloominess of the outlook he holds out gracious promises to the people on condition of their repentance. So late as the beginning of the reign of Jehoiakim, in the very discourse in which he warned that the temple in which they trusted should become as Shiloh, he says: "If ye thoroughly amend your ways and your doings; if ye thoroughly execute justice between a man and his neighbor; if ye oppress not the sojourner, the fatherless and the widow, and shed not innocent blood in this place, neither walk after other gods to your own hurt: then will I cause you to dwell in this place, in the land that I gave to your fathers, from of old even for evermore" (7:5-7).

But this early hope for the nation, with the progress of events, faded from the prophet's mind. So far as God was concerned there was hope. That was the message he received at the potter's house. The marred vessel could be made again into another vessel. "At what instant I shall speak concerning a nation, and concerning a kingdom, to pluck up and to break down and to destroy it; if that nation, concerning which I have spoken, turn from their evil, I will repent of the evil that I thought to do unto them" $(18: 7,8)$. But the divinely given message awakened no response; from the people's side it was hopeless : "They say, It is in vain; for we will walk after our own devices, and we will do every one after the stubbornness of his evil heart"' (18:12). Is it not a pathetic picture which we have here, of a man whose life was so bound up with the welfare of his people that he could say: "Oh that my head were waters, and mine eyes a fountain of tears, that I might weep day and night for the slain of the daughter of my people !" $(9: 1)$, yet finally coming to the realization that he preached to a doomed nation? More than once in face of his pleading he received the answer: "Pray not thou for this people, neither lift up cry nor prayer for them, neither make intercession to me; for I will not hear 
thee" $(7: 16)$. In response to one of his most touching appeals he was reminded of the two greatest intercessors in the past history of Israel, with the words, "Though Moses and Samuel stood before me, yet my mind would not be toward this people: cast them out of my sight, and let them go forth" (15:1). The sin of Judah was "written with a pen of iron, and with the point of a diamond"; it was "graven upon the tablet of their heart, and upon the horns of their altars" $(17: 1)$. During the latter part of the prophet's ministry he became resigned to the will of God. He counseled submission to the Chaldeans, but in the darkest hour, when the houses of the city were being torn down for a defense against the besiegers, he held up before them the changeless mercy of God and the promise of a restoration: "Thus saith Jehovah: If my covenant of day and night stand not, if I have not appointed the ordinances of Heaven and earth; then will I also east away the seed of Jacob, and of David my servant, so that I will not take of his seed to be rulers over the seed of Abraham, Isaac and Jacob: for I will cause their captivity to return, and will have mercy on them" $(33: 25,26)$.

Another way in which the pathos of Jeremiah's life appeals to us is in the delayed recognition of his unselfishness and greatness. The style and diction of Jeremiah's messages are not equal to those of Isaiah and others of the prophets. Their literary merit is not conspicuous, except where the sheer force and impressiveness of his ideas clothe themselves in appropriate language. But in disinterested devotion to his people and unwavering loyalty to truth and to God he has no superior. In regard for the word of the message committed to him he is an inspiration to the preacher. What God said was of infinitely more worth than popular favor and considerations of expediency: "The prophet that hath a dream, let him tell a dream; and he that hath my word, let him speak my word faithfully. What is the straw to the wheat? saith Jehovah. Is not my word like fire? saith Jehovah; and 
like a hammer that breaketh the rock in pieces?" $(23: 28$, 29). Probably no one was ever more conscious of a divine compulsion in the matter of his message: "If I say, I will not make mention of him, nor speak any more in his name, then there is in my heart as it were a burning fire shut up in my bones, and I am weary with forbearing, and I cannot contain" (20:9). No personal danger turned him aside from the message God had given him. One scene in his life very much resembles that of Stephen before the Sanhedrin when he was accused of speaking against the holy place and the law (Acts 6:13). Jeremiah also was put on trial for his life for a similar offense. He had dared to cry out against the inconsistency of those who trusted in the inviolability of the place of God's sanctuary, even while by their abominations they made his house a den of robbers. One of the most heroic moments of his life was that in which he said to his accusers, "As for me, behold, I am in your hand: do with me as is good and right in your eyes. Only know ye for certain that, if ye put me to death, ye will bring innocent blood upon yourselves, and upon this city, and upon the inhabitants thereof; for of a truth Jehovah hath sent me unto you to speak all these words in your ears"' $(26: 14,15)$.

The unselfish devotion of the prophet to his people showed itself in a remarkable way after the fall of Jerusalem. Because he had preached submission to the Chaldeans he was regarded with favor by the captors. Nebuchadnezzar himself gave command that they should look well to the prophet and do him no harm $(39: 12)$. The captain of his guard released Jeremiah, offering him the choice of going with him to Babylon, where he would no doubt have received every consideration and been given a position of honor, or of remaining with the miserable remnant of his people under Gedaliah. It adds to the beauty of the prophet's devotion that the drawings of his heart were evident to the heathen officer before his answer was given: "Now while he has not yet gone back, Go back 
then, said he, to Gedaliah . . . and dwell with him among the people" (40:5).

But we have to remember that we are looking upon a character that has been appraised by after generations and given a place among the greatest of the earth. The prophet himself received no such recognition. They accused him of sympathy with the Chaldeans and faithlessness to his own people during the siege of the city (37: 13), and put him in the dungeon as one whose preaching gave aid and comfort to the enemy and weakened the hands of the defenders of the city $(38: 4-6)$. They accused him of speaking falsely in the name of the Lord, influenced by base motives with a desire to destroy his people. When in response to their inquiry he had given his counsel against the flight of the remnant into Egypt, they said, "Thou speakest falsely: Jehovah our God hath not sent thee to say, Ye shall not go into Egypt to sojourn there; but Baruch the son of Neriah setteth thee on against us, to deliver us into the hand of the Chaldeans, that they may put us to death, and carry us away captive to Babylon" $(43: 2,3)$. So far as outward results were concerned the prophet saw only the failure of his mission. He had preached repentance to the nation, and they refused to return to Jehovah. When hope for the nation was gone, he had counseled King Zedekiah to surrender the city and save it from utter destruction; but though more than half convinced of the wisdom of this course he had been too wavering in face of the opposition of his princes to follow. this counsel. He had warned against going down into Egypt, and they disregarded his entreaties and took him down with them, unwilling to follow his advice but afraid to leave him behind. It is said by A. B. Davidson that, "like many of the world's greatest children, Jeremiah was little esteemed in his life, but when dead his spirit breathed out upon men and they felt its beauty and greatness" (Hastings D. B.). Such delayed recognition is surely one of the elements of pathos in the life of this great man. 
As a final illustration of the pathetic appeal of the life and ministry of Jeremiah it is proper that we speak of the deep feeling of the prophet himself over the coming disaster to his people. Here it is necessary to correct a false impression. Jeremiah has come to be known as the "weeping prophet", so that many think of him as by nature sad and lacrymose. This is a libel upon him. The sadness is all in the situation which he faced. A clear vision of what awaited his nation made optimism not only impossible but despicable. Moreover, his thoughts are mostly of the kind that lie too deep for tears. We can appreciate to the full the appeal of those closing days of the kingdom of Judah only as we see them through his eyes and know how he himself felt about them. Wordsworth, in his Ode on Immortality, in which he tells how the man beholds the splendid vision of youth fade into the light of common day, and the Heaven which lies about his infancy give place to the shades of the prison house which begin to close upon the growing boy, describes the feeling of one who becomes conscious of this:

"The clouds that gather round the setting sun

Do take a sober colouring from an eye

That hath kept watch o'er man's mortality!"'

It is not to be wondered at that the clouds which gathered round the setting sun of a nation should take a sober coloring from an eye that had kept watch over the moral and spiritual decay of that people.

It is perhaps best to close this discussion with a few examples from the prophet's own utterances which show the meaning of the calamity to him. Some of them are not only pathetic, but poetic in the highest degree. There is something weird in his picture of the desolation which is to come upon the land, as though he had taken his stand upon the wreck of a ruined world: "I beheld the earth, and, lo, it was waste and void; and the heavens, and they had no light. I beheld the mountains, and lo, they trembled, and all the hills moved to and fro. I be- 
held, and, lo, there was no man, and all the birds of the heavens were fled. I beheld, and, lo, the fruitful field was a wilderness, and all the cities thereof were broken down at the presence of Jehovah, and before his fierce anger" $(4: 23-26)$. Yet he was no stern prophet of judgment who announced without a tremor the evils which were about to come upon his people. He was more deeply touched than they. "Oh, that I could comfort myself", he says, "against sorrow! my heart is faint within me. Behold the voice of the cry of the daughter of my people from a land that is very far off' ' $(8: 18,19)$. It is a bold figure that, in view of the depopulated country, represents the beloved Rachel coming forth from her tomb and sitting solitary upon the heights of Benjamin to bewail her scattered children: "A voice is heard in Ramah, lamentation, and bitter weeping, Rachel weeping for her children; she refuseth to be comforted for her children, because they are not" (31:15). He had used all the resources of appeal to save the nation. He had appealed to God, who seemed to have become a stranger to his people: "O thou hope of Israel, the Saviour thereof in the time of trouble, why shouldest thou be as a sojourner in the land, and as a wayfaring man that turneth aside to tarry for a night", (14:8). He had appealed to the people, even when it seemed the night had overtaken them in their proud impenitence: "Hear ye, and give ear; be not proud; for Jehovah hath spoken. Give glory to Jehovah your God, before he cause darkness, and before your feet stumble upon the dark mountains, and, while ye look for light, he turn it into the shadow of death, and make it gross darkness. But if ye will not hear it, my soul shall weep in secret for your pride; and mine eye shall weep sore, and run down with tears, because Jehovah's flock is taken captive"' $(13: 15-17)$.

But the day of salvation for Judah was over. For pure sadness, what can exceed that lament over the closing of the season of hope? "The harvest is past, the summer is ended, and we are not saved"' $(8: 20)$. 